\title{
Israeli scientists woo Egypt
}

AMONG the documents that Egyptian President Anwar Sadat took back with him to Cairo after his recent extraordinary visit to Israel was a list of 36 international scientific conferences due to take place in Israel this year. Appended to that list was a request that Sadat facilitate the participation of Egyptian scientists in each of these conferences.

A much more far-reaching proposal for scientific cooperation was made immediately after Sadat's departure by Technion Professor Josef Rom, an aeronautical engineer now serving as a Likud member of the Knesset. Rom said that the current Israeli-Egyptian political dialogue should be accompanied by concrete measures to foster joint programmes in as many spheres as possible, among them science and technology. "For example," Professor Rom declared, "we must begin to plan and if possible to carry out bi-national projects such as the construction of atomic power stations and desalination plants in Sinai".

Such a scheme, in fact, was proposed many years ago by Dwight $D$. Eisenhower, and endorsed by other American leaders, all of whom thought it could help bring peace to the Middle East. Only later did it become clear that in the absence of peace, cooperative development projects were simply not feasible.

But before that scheme was finally shelved, American, Israeli and Egyptian scientists had come together at the Oak Ridge National Laboratory, then headed by Dr Alvin Weinberg, to work out details of how it could be carried out. They envisaged the installation of two reactors with a combined output of $1,000 \mathrm{MW}$ in the El Arish area, south of the Gaza Strip. The power generated was to be used by newly established industries producing chemicals, fertilisers, plastics, and aluminium, as well as for the operation of a plant to desalinate 1,000 million gallons per day of seawater-enough to irrigate some 300,000 acres of land in the deserts of Sinai and the neighbouring Negev. It was assumed that this American-financed programme would bring great material benefits to both Israel and Egypt and also provide employment opportunities for Arab refugees in the Gaza Strip.

In the interval most of these refugees have obtained jobs in Israel and many other things have changed. But $\mathrm{Dr}$ Gerald Stanhill, an Israeli scientist who helped work out some of the agricultural aspects of the scheme, hopes that it will be revived in one form or another.

At the same time, Dr Stanhill warns against the dangers of prematurely promoting "intensive, California-style agriculture" in a country like Egypt because this would involve an enormous investment in money and trained manpower as well as flooding Egypt's already overcrowded cities with "fellaheen" who would lose their jobs in the countryside and fail to find new ones in the cities.

But quite independent of the Sadat visit, Stanhill and his colleagues at the Volcani Centre of Agricultural Research have been considering how lowtechnology irrigation techniques similar to those used on Israeli moshavim (smallholders' settlements) could be introduced into the Egyptian countryside in a way that would substantially improve living standards without destroying the existing fabric of society. And these techniques-together with those from dozens of other countriesare being brought to the attention of the world's farmers and researchers through the efforts of the International Irrigation Information Centre (IIIC) located at Volcani.

Even so, personal contact is bound to be a more effective means of communication. This can be seen in the Gaza Strip, controlled by Israel since 1967. There Egyptian-trained agricultural instructors were taught Israeli techniques in irrigation and other spheres, and then brought them to local farmers. As a result, average annual production in agriculture has grown by $25.4 \%$ (as compared to $6-7 \%$ in Israel), while income per farmer has risen from $\$ 130$ to $\$ 732$.

There is enormous enthusiasm among Israeli researchers-be they working in agriculture, medicine, electronics or geophysics-to establish close contacts with their counterparts in Egypt, by far the largest and most developed scientific centre in the Arab world.

Weizmann Institute President Michael Sela was undoubtedly speaking for many others when he said this week that the Institute "soon hoped to have visiting scientists not only from Berkeley, London, Paris, and Tokyo, but also from Cairo and Alexandria". "Moreover," Professor Sela added, "if our researchers can spend their sabbaticals on the banks of the Thames or the Seine, there is no reason why they shouldn't be spending them on the banks of the Nile".

Nechemia Myers

\section{Euratom burns its public relations' fingers}

Relations between the European Commission and the environmentalist lobby got off to a bad start on the first day of last week's public hearings into nuclear energy with the publication of a report purporting to show that the European Atomic Energy Community (EURATOM) was planning a propaganda campaign to sway public opinion in favour of nuclear energy.

The "evidence" for this claim was a report "Design of a Task Force to Build Public Awareness and Support for Nuclear Power", prepared under a Euratom study contract, which was produced at press conferences held simultaneously in Brussels and Rome by the Italian Radical Party and antinuclear lobby.

The report, prepared by Allessandra Ovi of the Nuclear Engineering De- partment at the Polytechnic Institute of Milan, and written in November 1976, described the details of a communication process which would "successfully tackle" public opposition to nuclear power.

Techniques suggested for achieving this included making use of the "authority and credibility" of senior members of the medical hierarchy to diffuse a pro-nuclear message. The report recommends setting up a task force of experts who would "design adequate messages" to provide a coordinated response to nuclear opponents.

The commission's first response to the Italians' charge of manipulating public opinion was to dismiss the document as a "forgery". Later, however, when copies of the document were produced bearing the EURATOM Study Contract Number 605-76-03, the commission admitted its authenticity.

But according to the commission, the document bore no relation to official policy. It had apparently been a sub-contract made under a much larger contract (to which the contract number referred) on the general assessment of nuclear risk.

The report had been immediately disowned by EURATOM when its cxistence had become known in June of this year, with firm instructions that the line of inquiry it indicated should not be pursued further. How it got into the hands of the Italian environmentalists is not known; but its very existence, and the swift reaction which it aroused from the commission, was sufficient to add an initial jarring note to the three-day hearing.

David Dickson 